\title{
Empleo de cenizas de cáscara de arroz como adiciones en morteros
}

\author{
Use or rice husk ash an addition in mortar
}

\author{
JULIAN SALAS, PERCY CASTILLO, M." ISABEL SANCHEZ DE ROJAS, JANER VERAS (*) \\ Equipo de Viviendas de Bajo Coste. Instituto E. Torroja (C.S.I.C.) \\ Apartado $19.002-28080$ MADRID (España)
}

\section{RESUMEN}

Mediante la utilización de un horno-piloto de unos 400 litros de capacidad, en el que se realiza la combustión controlada de unos $40 \mathrm{~kg}$ de cáscara de arroz, se consigue una ceniza (RHA), sobre cuyas propiedades físico-químicas se centra el trabajo, para su empleo como adición.

Se presentan igualmente resultados sobre el poder de combustión de la cáscara $\simeq 4.000 \mathrm{kcal} / \mathrm{kg}$, superior a la mitad del valor de los carbones bituminosos normales.

Mediante mezclas de RHA con distintas proporciones de cal o de cemento portland, se han conseguido conglomerantes cuyas propiedades se estudian, tanto sobre morteros, como sobre hormigones.

El objetivo último del trabajo es mostrar la factible aplicabilidad de la cáscara de arroz (cuya "producción" mundial se estima en $500 \cdot 10^{6} \mathrm{~m}^{3}$ anuales) como adición, sin olvidar sus excelentes cualidades como combustible lo que hace especialmente idónea en países en vías de desarrollo, deficitarios en cemento y recursos energéticos.

\section{SUMMARY}

With the aid of a 400-litre capacity pilot furnace, in which $40 \mathrm{Kg}$ of rice husk is submitted to controlled combustion, an ash (RHA) is obtained for use as an addition, the physicochemical properties of which form the focal point of this work.

Results will also be presented for the combustion power of the husk $\simeq 4000 \mathrm{kcal} / \mathrm{kg}$, being greater than half the value for normal bituminous coals.

Conglomerates have been obtained by mixing RHA with different proportions of lime and portland cement, and their properties are studied with regard to both mortars and concretes.

The ultimate aim of the work is to demostrate how rice husk (world production of which is estimated at $500 \cdot 10^{6} \mathrm{~m}^{3}$ per annum) may be feasibly applied as an addition, without forgetting its excellent properties as a fuel, which makes it particularly siitable for developing countries with a shortage of cement and energy resources.

\section{INTRODUCCION Y JUSTIFICACION DEL TRABAJO}

Dentro del proyecto de investigación "Materiales, Tecnologías y Prototipos de Viviendas de Muy Bajo Coste" y como una faceta del objetivo materiales, se han estudiado con anterioridad posibles aplicaciones de la cáscara de arroz, como material aislante (1), y con objeto de conseguir hormigones ligeros (2).

Se aborda en este trabajo un tercer aspecto del estudio integral de posibles aplicaciones

(*) Deseamos dejar constancia de nuestro agradecimiento a nuestros compañeros de Instituto, Dra. Luxán y Dr. Sagrera por la colaboración recibida durante la realización de este trabajo.

\section{INTRODUCTION AND JUSTIFICATION OF THE WORK}

Potential applications were previously studied within the research project "Materials, Technologies and Prototypes for Very Low Cost Housing" and as a facet of the objective concerning materials, for rice husk as an insulating meterial (1) and in obtaining light concretes (2).

In this work, attention is turned to a third aspect of the integral study on the potential

(*) We would like to thank our colleagues at the Institute, Dr. Luxan and Dr. Sagrera for their collaboration throughout this work. 
de la cáscara de arroz en construcción: la ceniza de su combustión para su empleo como adición.

La bibliografía sobre utilización en construcción de la ceniza de cáscara de arroz, en adelante R. H. A. (iniciales de rice husk ash) como suele conocerse internacionalmente, es abundante y arranca varias décadas atrás, siendo Mentha (3) uno de los autores que de forma autorizada se ha distinguido en el tema. La literatura sobre otras aplicaciones de la cáscara de arroz datan de más de un siglo, según David F. Houston (4), quien llega a clasificar 262 referencias bibliograficas sobre propiedades y empleos de la cáscara de arroz.

La bibliografía más frecuente, con excepciones como la monografía recientemente preparada por R. Smith (5), se ocupa de los aspectos básicos, confinando los trabajos a resultados de técnicas de laboratorio.

La intención de este trabajo, en ciero modo reflejo de la visión multidisciplinar de sus autores, fue la de su planteamiento a nivel de producción piloto, aunque de modesta capacidad. La intención era el acortar el trecho entre el laboratorio y la aplicación, especialmente pensando en los países en vías de desarrollo (PVD).

Mentha (3) estima en $500 \cdot 10^{6}$ metros cúbicos la "producción" de cáscara mundial al año, lo que equivale aproximadamente a unos $80 \cdot 10^{6} \mathrm{t}$, que potencialmente pueden llegar a representar unos $12 \div 16 \cdot 10^{6} t$ de cenizas, lo que coincide con las estimaciones de Ray Smith (5). Sentados estos datos, obviamente no se plantea una solución a la escasez de cemento en los países en vías de desarrollo, sino una forma complementaria de paliar el déficit mediante un desecho agrícola que suele reunir la excelente circunstancia de encontrarse concentrado junto a los molinos de arroz.

No es objetivo preferente de este trabajo al incidir sobre el poder calorífico de la cáscara, aunque de ello se ocupa el apartado 2.2.

La cáscara a la que se refiere este trabajo procede del molino Divina Pastora de Sueca (Valencia, España) y presenta un peso específico de $124 \mathrm{~kg} / \mathrm{m}^{3}$, estando reseñadas en (2) por los autores, otros datos físicos de esta cáscara.

Una idea sobre el interés actual en torno al RHA lo da el hecho de haberse celebrado tres congresos internacionales monográficos sobre el tema en no muy largo plazo: en Peshawar (Pakistan, 1979), Alor Setar (Malasia, 1979), y Delhi (India, 1981). applications of rice husk in construction work: the ash resulting from its combustion for use as an addition.

The bibliography concerning the use of rice husk ash in construction, from now on referred to as R.H.A. (the initials of rice husk ash) as it is known internationally, is plentiful and originates several decades ago, with Mentha (3) being one of the authors who has distinguished himself as an authority on the subject. Literature on others rice husk applications goes back more than a century, according to David F. Houston (4), who was able to classify 262 bibliographical references to properties and uses of rice husk.

The bibliography, with exceptions such as the monograph recently prepared by $R$. Smith (5), is usually concerned with basic aspects, confining the work to results of laboratory techniques.

The aim of this, which is to a certain extent a reflection of the multidisciplinary vision of its authors, was that of an exposition at the level of pilot production, albeit of modest capacity. It was intended to narrow the gap existing beteween the laboratory and application, with spacific reference to developing countries $(D C)$.

Mentha (3) estimates that world husk "production" amounts to $500 \cdot 10^{6}$ cubic metres a year, which is roughly equivalent to $80 \cdot 10^{6} \mathrm{Tn}$, potentially representing $12 \div 16 \cdot 10^{6}$ Tn of ash, and coinciding with Ray Smith's estimations (5). Having established these facts, obviously no proposal for a solution to the shortage of cement in the developing countries in put forward, but rather a complementary way of palliating the deficit by means of an agricultural waste product that usually offers the excellent advantage of being found in concentrated form near rice mills.

The calorific power of rice husk does not constitute one of the foremost aims of this work, even though this subject is dealt with in Section 2.2.

The husk to which this work refers is produced at the mill in Divina Pastora de Sueca (Valencia, Spain) and has a specific weight of $124 \mathrm{~kg} / \mathrm{m}^{3}$. Further physical data concerning such husk are given by the authors in (2).

An indication of current interest in RHA is given by the fact that three monographic international congresses have been held on this subject in a short space of time in: Peshawar (Pakistan, 1979), Alor Setar (Malaysia, 1979) and Delhi (India, 1981). 


\section{DESCRIPCION DEL HORNO PILOTO}

Tras un período de trabajo en el laboratorio, al objeto de delimitar los parámetros básicos de la combustión de la cáscara -trabajo realizado por el Dr. Ruiz de Gauna-, con su colaboración se procedió a diseñar un hornopiloto que permitiese conseguir simultáneamente dos condiciones:

a) Reproducir con cierta precisión determinadas condiciones controlables de combustión y enfriamiento.

b) Capacidad de consecución de ceniza suficiente para la realización de ensayos de morteros y hormigones previstos.

En colaboración con la empresa SATER, se diseñó el horno esquematizado en las figuras 1 y 2 , con capacidad para 370 litros, lo que supone aproximadamente unos $45 \mathrm{~kg}$ de cáscara. Mediante cuatro quemadores de gas butano, de los que en la práctica sólo se utiliza uno, y durante un corto período de tiempo, se inicia la combustión de la cáscara, instante en el que se interrumpe la aportación energética externa. Mediante tres orificios situados en el cuerpo del horno - partes baja, media y alta - y con ayuda de un termopar de tipo TDAt, capaz para el campo comprendido entre $-60^{\circ} \mathrm{y}+1.200^{\circ} \mathrm{C}$, se han controlado las temperaturas del horno.



Fig. 1

\section{DESCRIPTION OF THE PILOT FURNACE}

After a period of work in the laboratory - carried out by Dr. Ruiz de Gauna- for the purpose of defining the basic parameters for the combustion of the husk, a pilot furnace was designed with his collaboration to enable the following two conditions to be ahieved simultaneously:

\section{a) The reproduction of certain controllable conditions for combustion and cooling with a certain amount of accuracy.}

b) The capacity to obtain sufficient ash to conduct tests on mortars and concretes as planned.

In collaboration with the company SATER, the furnace illustrated in Figs. 1 and 2 was designed with a capacity for 370 litres, which means approximately $45 \mathrm{Kg}$ of husk. The combustion of the husk is initiated with four butane gas burners, which, in practice, are used one at a time for a short period, and at this point, the external energy supply is cut off. Temperatures inside the furnace are controlled by means of three orifices situated on the body of the furnace - at the top, in the middle and at the bottom - and with the aid of a TDAt-type thermocouple, suitable for a range of $-60^{\circ} \mathrm{C}$ to $+1.200^{\circ} \mathrm{C}$.

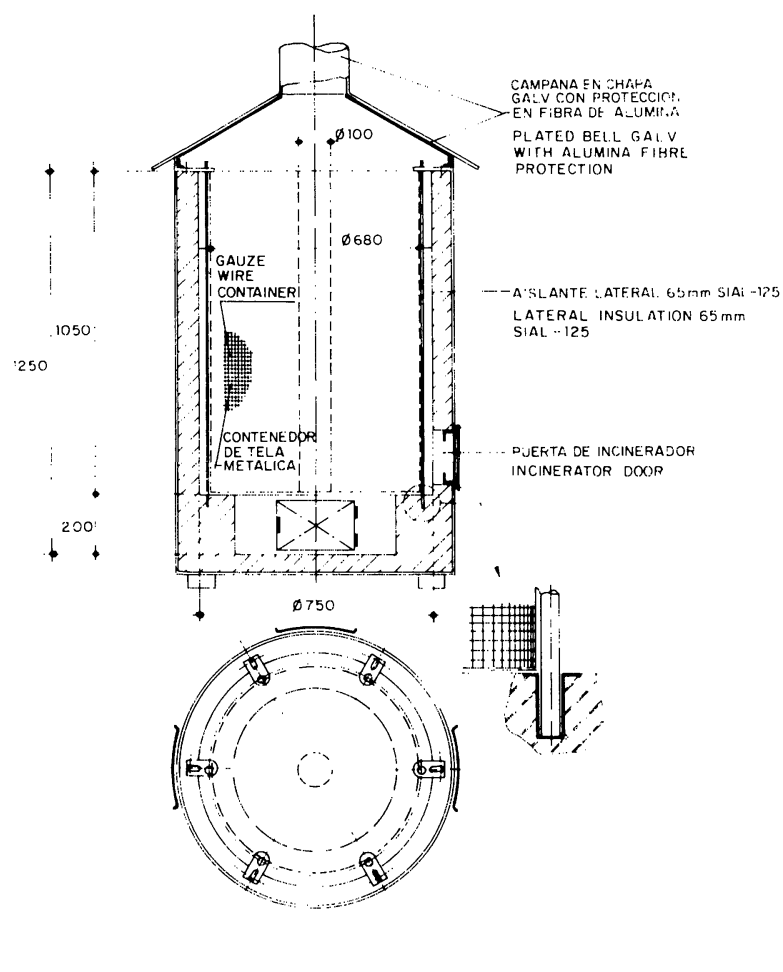

Fig. 2 


\subsection{Datos de la combustión}

El rendimiento medio de cenizas conseguidas en las diferentes combustiones puede estimarse del orden del $17,85 \%$, siendo $35 \mathrm{~kg}$ la cantidad de cáscara quemada en cada operación y consiguiéndose unos $6,25 \mathrm{~kg}$ de ceniza.

\subsection{Combustion data}

The average yield of ash obtained from different combustions may be estimated as being of the order or $17,85 \%$, with $35 \mathrm{Kg}$ of husk being burnt in each operation, producing about $6,25 \mathrm{Kg}$ of ash.

TABLA 1

Resultados comparativos de análisis de cenizas de cáscaras de arroz

\begin{tabular}{|c|c|c|c|c|c|c|c|c|c|c|c|}
\hline \multirow{2}{*}{$\begin{array}{l}\text { TEMPERATU- } \\
\text { RAS/TIEMPOS }\end{array}$} & \multirow{2}{*}{$\begin{array}{c}\text { Pérdi- } \\
\text { das por } \\
\text { calci- } \\
\text { nación }\end{array}$} & \multicolumn{10}{|c|}{ \% COMPOSICION DE OXIDOS } \\
\hline & & $\mathrm{SiO}_{2}$ & $\mathrm{Al}_{2} \mathrm{O}_{3}$ & $\mathrm{Fe}_{2} \mathrm{O}_{3}$ & $\mathrm{CaO}$ & MgO & $\mathrm{SO}_{3}$ & $\mathrm{Na}_{2} \mathrm{O}$ & $\mathrm{K}_{2} \mathrm{O}$ & $\mathrm{P}_{2} \mathrm{O}_{5}$ & Mno \\
\hline $\begin{array}{r}\text { Resultado de } \\
\text { este trabajo }\end{array}$ & & 91,26 & 0,94 & 0,37 & 2,15 & 0,88 & - & - & - & - & - \\
\hline $\begin{array}{c}450^{\circ} \mathrm{C} \text { y dos } \\
\text { horas (6) }\end{array}$ & 3,49 & 85,88 & 0,47 & 0,18 & 1,12 & 0,45 & 1,24 & 1,15 & 4,10 & 0,34 & 0,091 \\
\hline $\begin{array}{c}850^{\circ} \mathrm{C} \text { y dos } \\
\text { horas }(6)\end{array}$ & 1,84 & 87,72 & 0,40 & 0,16 & 1,43 & 0,36 & 1,25 & 1,11 & 3,96 & 0,30 & 0,091 \\
\hline Harsch G. (11) & - & 91,16 & - & 0,21 & 0,65 & 0,99 & 0,10 & - & 4,75 & - & - \\
\hline R. Hawkey (12) & - & 94,23 & - & 0,53 & 2,27 & 0,12 & - & 0,39 & & 2,22 & - \\
\hline
\end{tabular}

TABLE 1

Comparative results of chemical analysis of rice husk ash

\begin{tabular}{|c|c|c|c|c|c|c|c|c|c|c|c|}
\hline \multirow{2}{*}{$\begin{array}{c}\text { TEMPERATU- } \\
\text { RES/TIMES }\end{array}$} & \multirow{2}{*}{$\begin{array}{c}\text { Loss } \\
\text { on } \\
\text { ignition }\end{array}$} & \multicolumn{10}{|c|}{ \% COMPOSITION OF OXIDES } \\
\hline & & $\mathrm{SiO}_{2}$ & $\mathrm{Al}_{2} \mathrm{O}_{3}$ & $\mathrm{Fe}_{2} \mathrm{O}_{3}$ & $\mathrm{CaO}$ & MgO & $\mathrm{SO}_{3}$ & $\mathrm{Na}_{2} \mathrm{O}$ & $\mathrm{K}_{2} \mathrm{O}$ & $\mathrm{P}_{2} \mathrm{O}_{5}$ & Mno \\
\hline $\begin{array}{l}\text { Results of this } \\
\text { work }\end{array}$ & & 91,26 & 0,94 & 0,37 & 2,15 & 0,88 & - & - & - & - & - \\
\hline $\begin{array}{l}450^{\circ} \mathrm{C} \text { and two } \\
\text { hours (6) }\end{array}$ & 3,49 & 85,88 & 0,47 & 0,18 & 1,12 & 0,45 & 1,24 & 1,15 & 4,10 & 0,34 & 0,091 \\
\hline $\begin{array}{l}850^{\circ} \mathrm{C} \text { and two } \\
\text { hours (6) }\end{array}$ & 1,84 & 87,72 & 0,40 & 0,16 & 1,43 & 0,36 & 1,25 & 1,11 & 3,96 & 0,30 & 0,091 \\
\hline Harsch G. (11) & - & 91,16 & - & 0,21 & 0,65 & 0,99 & 0,10 & - & 4,75 & - & - \\
\hline R. Hawkey (12) & - & 94,23 & - & 0,53 & 2,27 & 0,12 & - & 0,39 & & 2,22 & - \\
\hline
\end{tabular}


En base de una amplia muestra de trabajos referenciados por D. F. Houston (4), dependiendo de las distintas procedencias de la cáscara y de los métodos de combustión empreados, las cantidades en peso de cenizas respecto al de cámara oscila desde un $19 \%$ hasta un $39 \%$, margen que evidencia situaciones muy diversas. La razón del bajo rendimiento en ceniza del horno empleado puede estar en las altas temperaturas que se alcanzan en el mismo, como se verá más adelante.

El inicio de la combustión se realiza mediante los quemadores de butano mencionados. Al conseguir una temperatura de $180^{\circ} \mathrm{C}$ en la parte inferior interna del horno se corta el suministro externo. Este periodo oscila entre cuatro y seis minutos.

La evolución de la temperatura e incidencias del proceso de combustión se recoge en la figura 3 , en la que puede comprobarse que la temperatura máxima se encuentra en el entorno de $1.000 \pm 25^{\circ} \mathrm{C}$. El tiempo de combustion puede estimarse en unos 90', siendo el enfriamiento del orden de seis horas.

La determinación de la gráfica temperaturastiempos, figura 3, proporcionó desde el primer
On the basis of an ample sample of referenced work produced by D.F. Houston (4), depending on the various origins of the husk and the combustion methods used, the quantities in weight of the ash with respect to the husk range from $19 \%$ to $39 \%$, a margin that indicates a great diversity of situations. The reason for the low yield of ash in the furnace used may be due to this reaching such high temperatures, as will be seen later on.

Combustion is initiated using the aforementioned butane burners. Once a temperature of $180^{\circ} \mathrm{C}$ has been reached in the lower section inside the furnace, the external supply is cut off. This period fluctuates between four and six minutes.

Temperature evolution and incidents occurring during the combustion process are shown in Fig. 3 , in which it can be seen that the maximum temperature is about $1.000 \pm 25^{\circ} \mathrm{C}$. Combustion time may be estimated as being about 90', and cooling time in the region of six hours.

Plotting the temperature-time graph, Fig. 3, made it certain right from the start that with a

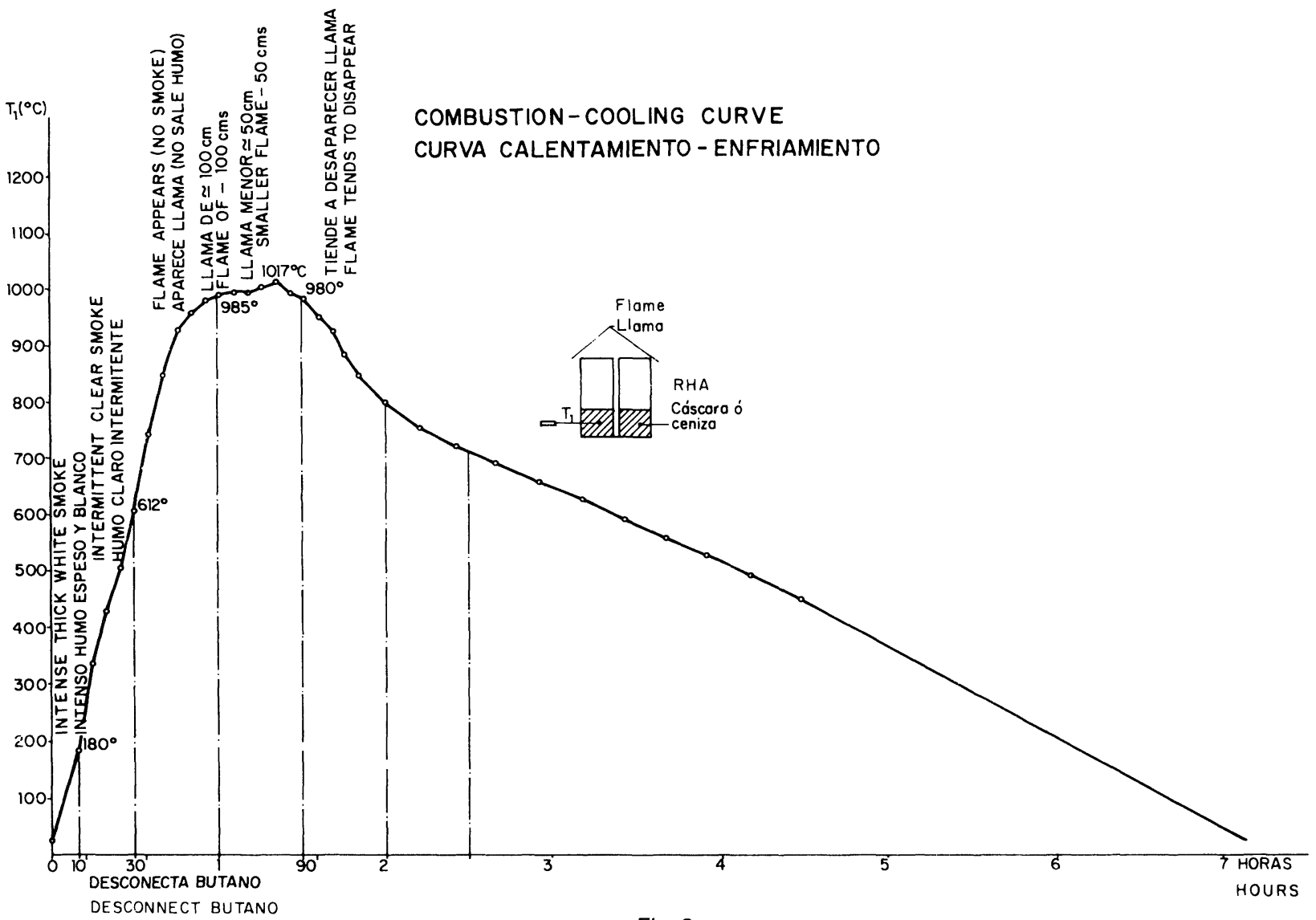

Fig. 3 
momento la certeza de que con los $1.000^{\circ} \pm 25^{\circ} \mathrm{C}$ de temperatura máxima y tiempo de calentamiento-enfriamiento del orden de siete horas, la ceniza obtenida se diferenciaría de las que son objeto de estudio en la literatura existente. El exceso de aislamiento-estanquidad del horno proyectado son causas de esta diferenciación, aunque por otra parte, permite obtener ceniza de buena homogeneidad, como se puede ver en los resultados de la Tabla 2 . maximum temperature of $1.000^{\circ} \pm 25^{\circ} \mathrm{C}$ and a heating-cooling time of the order of seven hours, the ash obtained would be different from those submitted to study in existing literature. This difference is due to the excessive insulation and watertightness of the furnace projected although, on the other hand, it enables an ash to be obtained with excellent homogeneity, as can be seen from the results in Table 2.

TABLA 2

\begin{tabular}{|c|c|c|c|c|c|c|c|c|c|}
\hline MUESTRAS & $\begin{array}{c}\text { Pérdidas } \\
\text { por } \\
\text { calcinación }\end{array}$ & $\begin{array}{l}\text { Residuo } \\
\text { insoluble }\end{array}$ & $\mathrm{SiO}_{2}$ & $\mathrm{Al}_{2} \mathrm{O}_{3}$ & $\mathrm{Fe}_{2} \mathrm{O}_{3}$ & $\mathrm{CaO}$ & MgO & $\mathrm{SO}_{3}$ & TOTAL \\
\hline $\begin{array}{l}\text { Muestra "A" } \\
\text { Desecada a } 105^{\circ} \mathrm{C}\end{array}$ & 2,90 & 0,17 & 88,61 & 0,92 & 0,35 & 2,09 & 0,86 & - & 95,90 \\
\hline $\begin{array}{l}\text { Muestra "A" } \\
\text { Calcinada a } 1.000^{\circ} \mathrm{C}\end{array}$ & - & 0,17 & 91,26 & 0,94 & 0,37 & 2,15 & 0,88 & - & 95,77 \\
\hline $\begin{array}{l}\text { Muestra "B" } \\
\text { Desecada a } 105^{\circ} \mathrm{C}\end{array}$ & 4,90 & 0,44 & 86,45 & 0,73 & 1,89 & 2,06 & 1,01 & - & 97,48 \\
\hline $\begin{array}{l}\text { Muestra "B" } \\
\text { Calcinada a } 1.000^{\circ} \mathrm{C}\end{array}$ & - & 0,46 & 90,90 & 0,77 & 1,99 & 2,17 & 1,06 & - & 97,34 \\
\hline $\begin{array}{l}\text { Muestra "C" (*) } \\
\text { Desecada a } 105^{\circ} \mathrm{C}\end{array}$ & 3,72 & 0,21 & 84,14 & 1,62 & 0,93 & 3,60 & 0,90 & 0,24 & 98,42 \\
\hline
\end{tabular}

(*) Esta muestra dio un contenido de $0,16 \%$ de $\mathrm{Na}_{2} \mathrm{O}$ y del $2,90 \%$ de $\mathrm{K}_{2} \mathrm{O}$, sobre ella se determinó la sílice activa resultando el valor mencionado, $79,86 \%$

TABLE 2

\begin{tabular}{|c|c|c|c|c|c|c|c|c|c|}
\hline SAMPLES & $\begin{array}{c}\text { Loss } \\
\text { on } \\
\text { ignition }\end{array}$ & $\begin{array}{l}\text { Insoluble } \\
\text { Residue }\end{array}$ & $\mathrm{SiO}_{2}$ & $\mathrm{Al}_{2} \mathrm{O}_{3}$ & $\mathrm{Fe}_{2} \mathrm{O}_{3}$ & $\mathrm{CaO}$ & MgO & $\mathrm{SO}_{3}$ & TOTAL \\
\hline $\begin{array}{l}\text { Sample "A" } \\
\text { Dried at } 105^{\circ} \mathrm{C}\end{array}$ & 2,90 & 0,17 & 88,61 & 0,92 & 0,35 & 2,09 & 0,86 & - & 95,90 \\
\hline $\begin{array}{l}\text { Sample "A" } \\
\text { Calcined at } 1.000^{\circ} \mathrm{C}\end{array}$ & - & 0,17 & 91,26 & 0,94 & 0,37 & 2,15 & 0,88 & - & 95,77 \\
\hline $\begin{array}{l}\text { Sample "B" } \\
\text { Dried at } 105^{\circ} \mathrm{C}\end{array}$ & 4,90 & 0,44 & 86,45 & 0,73 & 1,89 & 2,06 & 1,01 & - & 97,48 \\
\hline $\begin{array}{l}\text { Sample "B" } \\
\text { Calcined at } 1.000^{\circ} \mathrm{C}\end{array}$ & - & 0,46 & 90,90 & 0,77 & 1,99 & 2,17 & 1,06 & - & 97,34 \\
\hline $\begin{array}{l}\text { Sample "C" (*) } \\
\text { Dried at } 105^{\circ} \mathrm{C}\end{array}$ & 3,72 & 0,21 & 84,14 & 1,62 & 0,93 & 3,60 & 0,90 & 0,24 & 98,42 \\
\hline
\end{tabular}

$\left(^{\star}\right)$ This sample produced a content of $0,16 \% \mathrm{Na}_{2}$ and $2,90 \% \mathrm{~K}_{2} \mathrm{O}$, the reactive silica content was a determined from this, giving the value indicated: $79,86 \%$. 
En base a la práctica semi-industrial, en India, Nepal y Pakistán, descrita por R. Smith (5), se plantea la necesidad de limitar la temperatura de combustión de la cáscara a $700^{\circ} \mathrm{C}$ para obtener ceniza amorfa que pueda ser reactiva con la cal. Ello tiene como contrapartida la necesidad de tiempo de molienda grande - de tres a cinco horas - ya que, como el autor citado afirma, las cenizas especialmente quemadas son más blandas que las quemadas a menores temperaturas y por tanto necesitan menos tiempo de molienda.

Al-Khalaf an Yousiff (6) proporcionan gráficas en las que se recogen los valores de relación entre: tiempo de molienda ( 0 a 7 horas), finura $\left(3.000 \div 15.000 \mathrm{~cm}^{2} / \mathrm{g}\right)$ y temperatura de combustion durante 2 horas $\left(450^{\circ} \mathrm{C} \div 700^{\circ} \mathrm{C}\right)$. Los resultados de este trabajo son opuestos a la afirmación de Smith de que a mayor temperatura de combustión, es necesario un menor tiempo de molienda para conseguir igual finura, expresada en términos de superficie específica. La explicación de los autores citados se basa en que, a menor temperatura, existen mayor cantidad de partículas de carbón que, por ser más finas, tienen una mayor superficie específica comparadas con las partículas de sílice.

La práctica más generalizada a base de combustiones de cáscara a temperaturas de aproximadamente $850^{\circ} \mathrm{C}$, durante unas dos horas, muestran la presencia de sílice en una base cristalina de cuarzo. Igualmente muestra que la sílice permanece en estado amorfo cuando las temperaturas permanecen entre $450 \div 700^{\circ} \mathrm{C}$ durante $3 \div 4$ horas. Dado que las formas cristalinas presentan menor reactividad que las amorfas, es esencial que la combustión de la cáscara no supere temperaturas muy elevadas (del orden de $\left.900^{\circ} \mathrm{C}\right)$

\subsection{Poder calorífico de la cáscara}

No se plantea este trabajo como objetivo la utilización del importante poder calorífico de la cáscara, aunque resulta interesante señalar como valor complementario de la simple consecución de RHA.

D. F. Houston (4) cita bastantes trabajos donde se estudia este punto, cifrando el poder calorífico de la cáscara entre $5.000 \div 6.000$ BTU por libra de cáscara o, lo que es equivalente, entre $3.300 \div 3.600 \mathrm{kcal} / \mathrm{kg}$, es decir, valores próximos a la mitad del de un carbón bituminoso. Coinciden básicamente con estos datos los trabajos de R. C. Maheshwari y Ojha (7), Bartha y Huppertz (8), llegando Fieger (9) a afirmar tras
On the basis of semi-industrial practice in India, Nepal and Pakistan, as described by $R$. Smith (5), a need is seen for limiting the combustion temperature of the husk to $700^{\circ} \mathrm{C}$ so as to obtain amorphous ash that can react with lime. However, this means that milling time is necessarily prolonged -from three to five hours - since, as the aforementioned author points out, specially burnt ash is softer than ash which is burnt at lower temperatures and therefore requires less milling time.

Al-Khalaf an Yousiff (6) provide graphs giving values for the ratio between: milling time $(0$ to 7 hours), fineness $\left(3.000 \div 15.000 \mathrm{~cm}^{2} / \mathrm{g}\right.$ ) and combustion temperature for two hours $\left(450^{\circ} \mathrm{C} \div 700^{\circ} \mathrm{C}\right)$. The results of this work refute Smith's statement that at a higher temperature less milling time is required to obtain the same degree of fineness expressed in terms of specific surface. The explanation of the aforementioned authors is based on the fact that at a lower temperature there is a greater quantity of carbon particles which, since they are much finer, have a greater specific surface compared to silica particles.

The most widespread practice based on the combustion of husk at temperatures of approximately $850^{\circ} \mathrm{C}$ throughout a two-hours period show the presence of silica in a crystalline quartz stage. It also shows that silica remains in an amorphous state when temperatures remain between $450 \div 700^{\circ} \mathrm{C}$ for $3 \div 4$ hours. Given that crystalline forms present less reactivity than amorphous forms, it is essential that the combustion of the husk should not exceed very high temperatures (of the order of $900^{\circ} \mathrm{C}$ ).

\subsection{Calorific power of the husk}

This work does not include the use of the important calorific power of the husk among its objectives, although it is interesting to draw attention to this as a complementary value in obtaining RHA.

D. F. Houston (4) mentions quite a few works in which this point is studied, calculating the calorific power of the husk to be between $5.000 \div 6.000$ BUT per pound of husk, or between $3.300 \div 3.600 \mathrm{Kcal} / \mathrm{Kg}$, which amounts to the same thing, that is to say, values approaching half of that of a bituminous coal. The works of R. C. Maheshwari and Ojha (7) and Bartha and Huppertz (8) basically coincide with these 
determinación con la bomba de oxígeno, que dicho valor es de 6.275 BUT/libra, sin duda, un valor extremo. Aproximadamente puede afirmarse que el poder de combustión de $3 \mathrm{~kg}$ de cáscara es similar al de $1 \mathrm{~kg}$ de fuel-oil n.० 2 .

Al objeto de ratificar los valores anteriores, se ha deteminado en los laboratorios de la E.T.S. Ing. Industriales de Madrid, el poder de combustión de una muestra de la cáscara de arroz estudiada, determinándose que la potencia calorífica superior de la cáscara es de $4.441 \mathrm{Kcal} / \mathrm{Kg}$, valor que hemos contrastado de forma precisa, ya que resulta bastante superior a todo lo indicado por la literatura existente, incluso al valor aportado por Fieger.

\section{ESTUDIO FISICO-QUIMICO DE LA CENIZA DE CASCARA DE ARROZ (RHA)}

La caracterización de la ceniza de cáscara de arroz RHA, producida en las condiciones de operación fijadas como "standard" en el horno piloto, ha quedado determinada por los siguientes aspectos: análisis químico, molturabilidad (tiempo requerido para alcanzar una finura determinada); análisis granulométrico y determinación de la superficie específica Blaine; determinación del peso específico; análisis cualitativo por difracción de rayos $X$ y espectroscopía de absorción infrarroja; determinación del contenido de sílice reactiva y valoración de su aptitud como adición activa al cemento.

\subsection{Análisis químico}

Realizado según el "Pliego de prescripciones técnicas generales para la recepción de cementos RC-75" (10), previa fusión alcalina para solubilización de la muestra. data, with Fieger (9) reaching the conclusion, following his use of an oxygen pump to make his determination, that this value is 6.275 BUT/pound, this being, without doubt, an extreme value. It may be roughly stated that the combustion power of three $\mathrm{Kg}$ of husk is similar to that of one $\mathrm{Kg}$ of fuel-oil no. 2.

In order to ratify the preceding values, the combustion power of a sample of the rice husk under study has been determined in the laboratories of E.T.S. Ing. Industriales of Madrid, concluding that the greatest calorific power of the husk is $4441 \mathrm{Kcal} / \mathrm{Kg}$; this value has been minutely contrasted since it is substantially greater than anything indicated by existing literature, including the value given by Fieger.

\section{PHYSICOCHEMICAL STUDY OF THE RICE HUSK ASH (RHA)}

Characterization of the rice husk ash RHA, produced under the conditions of operation established as "standard" in the pilot furnace, has been determined by the following aspects: chemical analysis; millability (time required to reach a certain degree of fineness); granulometric analysis and determination of the specific Blaine surface; determination of specific weight; qualitative analysis by $X$-ray diffraction and spectroscopy of infrared absorption; determination of the content of reactive silica and assessment of its aptitude as an active addition for cement.

\subsection{Chemical analysis}

Conducted according to the "General technical specifications for the reception of $R C-75$ cements" (10) following alkaline fusion for the solubilisation of the sample.

\section{Resultados obtenidos}

$$
\begin{aligned}
& \text { Pérdida por calcinación..... - } \\
& \text { Residuo insoluble......... } 0,17 \\
& \text { Anhidrido Silícico, } \mathrm{SiO}_{2} \ldots \ldots \quad 91,26 \\
& \text { Oxido Alumínico, } \mathrm{Al}_{2} \mathrm{O}_{3} \ldots \ldots \quad 0,94 \\
& \text { Oxido Férrico, } \mathrm{Fe}_{2} \mathrm{O}_{3} \ldots \ldots . \quad 0,37 \\
& \text { Oxido Cálcico, } \mathrm{CaO} \text {....... 2,15 } \\
& \text { Oxido Magnésico, } \mathrm{MgO} \ldots \quad 0,88
\end{aligned}
$$

\section{Results obtained}

\begin{tabular}{lr} 
Loss on ignition ............ & \multicolumn{1}{c}{-} \\
Insoluble residue $\ldots \ldots \ldots \ldots$ & 0,17 \\
Silicon dioxide, $\mathrm{SiO}_{2} \ldots \ldots \ldots$ & 91,26 \\
Aluminium oxide, $\mathrm{Al}_{2} \mathrm{O}_{3} \ldots \ldots$ & 0,94 \\
Ferric oxide, $\mathrm{Fe}_{2} \mathrm{O}_{3} \ldots \ldots \ldots \ldots$ & 0,37 \\
Calcium oxide, $\mathrm{CaO} \ldots \ldots \ldots$ & 2,15 \\
Magnesium oxide, $\mathrm{MgO} \ldots \ldots$ & 0,88
\end{tabular}


La composición química de la ceniza puede considerarse absolutamente normal de acuerdo con la bibliografía consultada, destacando un apreciable contenido de sílice de cuyas características mineralógicas y cristalográficas dependerá la mayor o menor actividad para combinarse con cal y formar silicatos cálcicos hidratados en medio acuoso, con capacidad para desarrollar propiedades cementicias. En la Tabla 1 se recogen, a título comparativo, resultados de análisis de distintos trabajos, y en la Tabla 2 los resultados obtenidos sobre tres muestras de RHA después de desecar $\left(105^{\circ} \mathrm{C}\right)$ y de calcinar $\left(1.000^{\circ} \mathrm{c}\right)$ respectivamente.

La normativa española (UNE 80-302) (13) señala que el porcentaje de sílice reactiva que deben poseer las puzolanas naturales y cenizas volantes tiene que ser superior al $25 \%$. Esta sílice se determina por diferencia entre la sílice total y la sílice que queda inalterada como residuo insoluble, una vez realizado un ataque mediante ácido clorhídrico $(\mathrm{HCl})$ e hidróxido potásico $(\mathrm{KOH})$.

Para la ceniza de cáscara de arroz estudiada este valor de sílice reactiva dio un resultado del $79,86 \%$, lo que la hace muy apropiada, según éste dato, para su utilización como adición.

En la Tabla 2 se recogen los resultados analíticos de tres muestras de ceniza, obtenidas con el horno piloto en días diferentes, pero en similares condiciones, en la última de las cuales se realizó la determinación de la sílice reactiva obteniéndose el valor anteriormente mencionado.

\subsection{Determinación del peso específico y densidad aparente}

La ceniza estudiada presenta un peso específico de $2,05 \mathrm{~g} / \mathrm{cm}^{3}$ y una densidad aparente de $0,7 \mathrm{~g} / \mathrm{cm}^{3}$ para el peso específico; A. M. Neville (14) fija el peso específico de las puzolanas entre $2,10 \div 2,40$ $\mathrm{g} / \mathrm{cm}^{3}$.

El peso específico y la densidad aparente de la ceniza revisten importancia en las posibilidades de su utilización como adición activa al cemento y al hormigón, y por su influencia en la densidad de los mismos, lo cual hace variar sus condiciones de empleo y expendio.

\subsection{Molturabilidad y superficie específica Blaine}

Se han molido muestras de $10 \mathrm{~kg}$, cada una en un molino tubular cargado con $60 \mathrm{~kg}$ de
The chemical composition of the ash may be considered absolutely normal in accordance with the bibliography consulted, there being a very noticeable amount of silica on the mineralogical and crystallographical characteristics of which will depend greater or lesser activity to combine with lime and form hydrated calcium silicates in an aqueous medium, with the capacity to develop properties pertaining to cement. Table 1 provides the results of analyses of various work for the purposes of comparison, and Table 2 the results obtained for theree RHA samples after drying $\left(105^{\circ} \mathrm{C}\right)$ and calcination $\left(1.000^{\circ} \mathrm{C}\right)$ respectively.

Spanish standard UNE 80-302 (13) indicates that the percentage of reactive silica that should be contained in natural puzzolanas and fly ash must be greater than $25 \%$. This silica is determined by the difference between the total amount of silica and the silica that remains unchanged as an insoluble residue, following attack by hydrochloric acid $(\mathrm{HCl})$ and potassium hydroxide $(\mathrm{KOH})$.

For the rice husk ash unde study, this value for reactive silica turned out to be $79,86 \%$, making it highly suitable, where this fact is concerned, for use as an addition.

Table 2 shows the analytic results for three ash samples, obtained with the pilot furnace on different days, but in similar conditions, in the last of which the amount of reactive silica was determined, obtaining the value mentioned above.

\subsection{Determination of specific weight and aparent density}

The ash submitted to study presents a specific weight of 2,05 $\mathrm{g} / \mathrm{cm}^{3}$ and an apparent density of $0,7 \mathrm{~g} / \mathrm{cm}^{3}$. Al-Khalaf an Yousif (9) offer a value of $2,14 \mathrm{~g} / \mathrm{cm}^{3}$ for the specific weight and A. M. Neville (14) sets the specific weight of the puzzolana between $2,10 \div 2,40 \mathrm{~g} / \mathrm{cm}^{3}$.

The specific weight and apparent density of the ash are important when considering its possibilities for use as an active addition for cement and concrete and on account of its influence on the density of these, which means varying its conditions of use and expenditure.

\subsection{Millability and specific Blaine surface}

Samples each weighing $10 \mathrm{Kg}$ were ground up in a tubular mill loaded with $60 \mathrm{Kg}$ of steel 
Cylpebs de acero, extrayendo muestras cada 5 minutos para determinación de superficie específica Blaine (15). Habiendo fijado obtener, como objetivo, una ceniza con un Blaine aproximado de $4.500 \mathrm{~cm}^{2} / \mathrm{g}$ para la preparación de las muestras programadas; éste valor se consigue a los 35 minutos de molienda.

El valor de $4.500 \mathrm{~cm}^{2} / \mathrm{g}$ de Blaine se fijó para establecer una relación adecuada en las mezclas ceniza-cal y cemento-ceniza.

La molturabilidad de la ceniza puede considerarse bastante alta, comparándola con las referencias de la bibliografía consultada. Esta facilidad de molienda puede atribuirse a la elevada temperatura de combustión del horno. La temperatura óptima deberá ser establecida en función de su influencia en la actividad de la sílice obtenida fundamentalmente, pero considerando los factores que influyen en los costos de producción. El tiempo requerido de molienda es un dato importante por el consumo de energía eléctrica, ocupación del equipo y mano de obra que supone.

El método Blaine varía sustancialmente con la porosidad del material, y ésta,

correspondientemente, con las condiciones en las que ha sido quemada la ceniza; por esta razón conviene incluir otros ensayos complementarios, como el análisis granulométrico para conocer la distribución por tamaños de partículas y el método Hardgrove para medición de la molturabilidad de la ceniza.

\subsection{Difracción de Rayos $X$}

El equipo utilizado es un aparato Philips, modelo PW-1700, con tubo de Rayos $X$ y con ánodo de cobre. Para la preparación de las muestras se utiliza una prensa semiautomática, marca Herzog, tipo Hoifp, alimentada con aire a presión. Con ella se compactan las muestras de polvo sobre anillos de aluminio usados como portamuestras.

Los difractogramas correspondientes a las muestras A y B de ceniza de cáscara de arroz, se reflejan en las figuras $4 a$ y $4 b$, donde se comprueba que en este tipo de materiales existen pocos picos que indiquen la existencia de compuestos cristalinos (6) y (16), si bien la cristalinidad de la ceniza estará relacionada con el proceso de combustión de la misma (6), según la cual tendrá lugar la formación de tridimita, cristobalita o cuarzo (16).

La sílice presente en la ceniza se encontrará pues, en su mayor parte, como sílice amorfa,
Cylpebs, with samples being extracted every 5 minutes to determine the specific Blaine surface (15). Having established the aim of obtaining an ash with a Blaine of approximately $4.500 \mathrm{~cm}^{2} / \mathrm{g}$ for the preparation of the programmed samples, this value is obtained after 35 minutes of milling.

The value of $4.500 \mathrm{~cm}^{2} / \mathrm{g}$ Blaine was fixed to establish an adequate ratio in the ash-lime and cement-ash mixes.

The millability of the ash may be considered quite high when compared to references from the bibliography consulted. This facility for milling may be attributed to the high combustion temperature of the furnace. optimum temperature should be basically established according to its influence on the activity of the silica obtained; however, factors affecting production costs should also be taken into account. The amount of milling time required is important on account of the consumption of electric power, and the occupation of equipment and labour that this entails.

The Blaine method varies substantially with the porosity of the material, which also varies accordingly with the coditions in which the ash has been burnt. For this reason, it would be wise to include other complementary tests, such as the granulometric analysis to ascertain the distribution of particles according to size and the Hardgrove method to measure the millability of the ash.

\subsection{X-Ray diffraction}

The equipmet used is a Philips device, model PW-1700, with X-Ray tube and copper anode. For the preparation of the samples, a semi-automatic press made by Herzog, type Hoifp, was used and supplied with air under pressure. This is used to compact the powder samples over aluminium rings acting as sample-holders.

The diffraction patterns corresponding to samples $A$ and $B$ of rice husk ash are shown in Figs. $4 a$ and $4 b$, in which it can be seen that for this type of material there are very few peaks indicating the existtence of crystaline composites (6) and (16). The crystallinity of the ash will, however, be related to its combustion (6), according to which, tridymite, cristobalite, or quartz will be formed (16).

The silica present in the ash will therefore mainly be found as amorphous silica, which will 


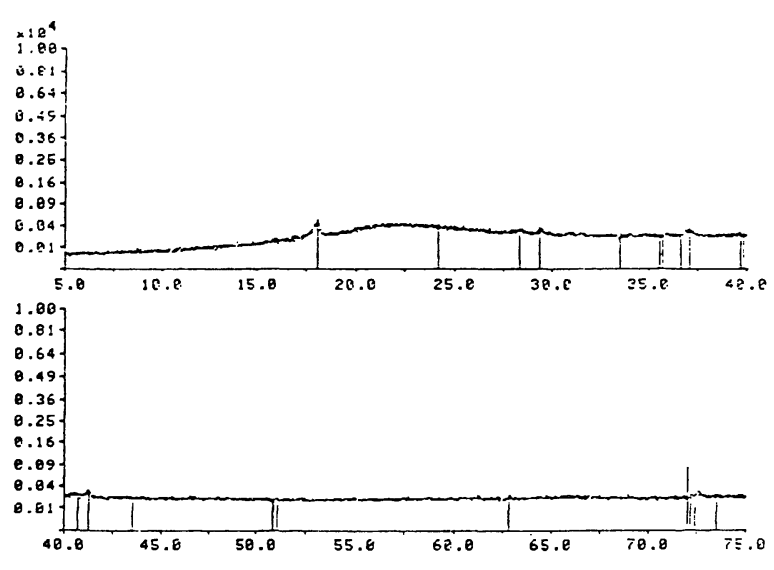

Fig. $4 a$

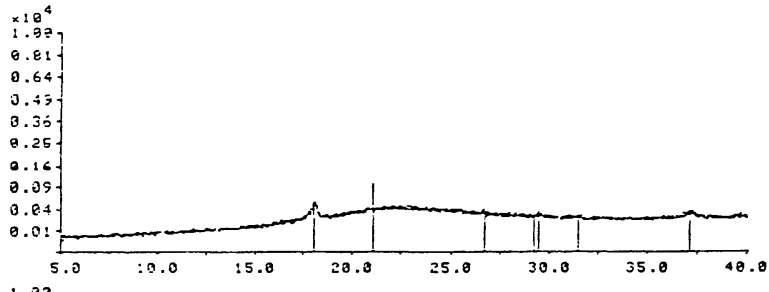

1.83
$0.3:$

$0.3:$

0.54.
0.49
0.36
0.25

0.36 .

0.25

0.89

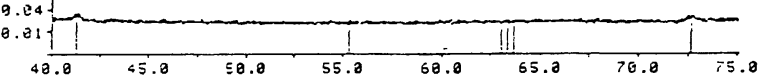

Fig. $4 b$ lo que favorecerá la actividad de estos materiales, al ser esta sílice mucho más reactiva al ataque de la cal, que de encontrarse en un estado de mayor ordenación.

La interpretación de los diagramas de difracción de Rayos $X$ atribuye los picos a la presencia de tridimita y cristobalita, formas de sílice a altas temperaturas. Conforme aumenta la temperatura de combustión, la tridimita, como forma más estable, resulta predominante sobre la cristobalita. Para combustiones a bajas temperaturas (cenizas fundamentalmente de color negro), prevalecen proporciones considerables de sílice amorfa.

\subsection{Espectroscopía de absorción infrarroja (IR)}

Comprobado por difracción de Rayos $X$ que la ceniza de cáscara de arroz está constituida, en su mayor parte, por compuestos de naturaleza amorfa, hace que sea necesario utilizar otra técnica en su estudio que sea idónea, tanto para los compuestos cristalinos, como para los no cristalinos, deduciendo de la bibliografía consultada (17) (18) que la espectroscopia de absorción IR es una técnica apta para la caracterización de este tipo de materiales. favour the activity of these materials, since this type of silica is much more reactive to the attack of lime, than that found in a more ordered state.

In the X-Ray diffraction diagrams, the peaks are interpreted as being due to the presence of tridymite and cristobalite, forms of silica at high temperatures. As the combustion temperature rises, tridymite, being the most stable form, becomes predominant over cristobalite. For combustion at low temperatures (ash which is basically black), amorphous silica prevails in considerable proportions.

\subsection{Spectroscopy of infrared (IR) absorption}

Having verified, by means of X-Ray diffraction, that rice husk is mainly composed of composites of an amorphous nature, means that it is necessary to use another tecnique for this analysis suiable for both crystalline and non-crystalline composites, with the conclusion being drawn from the bibliography consulted (17) (18) that spectroscopy of IR absorption constitutes a suitable technique for characterizing this type of material.

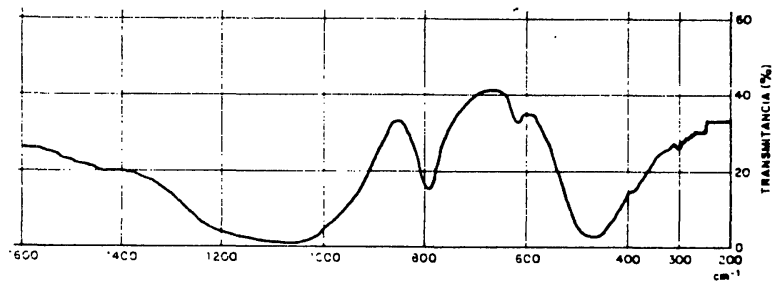

Fig. 5 
La figura 5 reproduce el espectro IR de la $\mathrm{RHA}$, del mismo se deduce que:

- La zona de $1.200 \div 900 \mathrm{~cm}^{-1}$ corresponde a vibraciones de valencia $\left(\nu_{3}\right)$ de tetraedros $\mathrm{SiO}_{4}$, mientras que la banda próxima a 500 $\left(470 \mathrm{~cm}^{-1}\right)$ se debe a vibraciones $\left(\nu_{4}\right)$ de deformación Si-O-Si. En ambos casos se observan dominios de absorción amplios y no bandas netas, característicos de sustancias, en su mayor parte, amorfas.

- La banda existente a $790 \mathrm{~cm}^{-1}$ corresponde a vibraciones de la sílice amorfa.

\subsection{Estudio de la actividad puzolánica de ceniza de cáscara de arroz}

El valorar la posible actividad puzolánica de un material ha sido objetivo principal de numerosos trabajos, dando lugar a distintos métodos de evaluación, basados en aspectos diferentes de un mismo hecho.

Para el presente estudio, y en base a la experiencia de la Dra. Luxán (19), se ha llevado a cabo un ensayo que valora la reacción material/cal apagada, mediante la prueba mecánico-resistente a flexotracción y compresión de morteros.

\subsubsection{Materiales empleados}

- Ceniza de cáscara de arroz. Esta ceniza se molió hasta alcanzar una finura de 4.500 $\mathrm{cm}^{2} / \mathrm{g}$ Blaine, que se consideró idónea para estudios posteriores.

- Cal apagada. La cal empleada es un hidróxido calcico, con una riqueza en $\mathrm{Ca}(\mathrm{OH})_{2}$ superior al $90 \%$ y un contenido en $\mathrm{CO}_{2}$ inferior al $7 \%$.

- La arena empleada en el mortero es la normalizada en el RC-75 (10) para el ensayo de cementos.

- Agua de amasado. La relación agua/conglomerante es de 0,5 (aunque este valor se puede ver incrementado por algunos materiales hasta conseguir la consistencia adecuada para una buena compactación).

\subsubsection{Procedimiento}

Las probetas son prismas de $4 \times 4 \times 16 \mathrm{~cm}$, fabricados según las especificaciones para mortero de cemento descritas en el RC-75. El
Fig. 5 reproduces the IR spectre of RHA and from this it can be deduced that:

- The area of $1.200 \div 900 \mathrm{~cm}^{-1}$ corresponds to stretching vibrations $\left(v_{3}\right)$ of $\mathrm{SiO}_{4}$ tetrahedrons, whereas the band approaching $500\left(470 \mathrm{~cm}^{-1}\right)$ is due to vibrations $\left(v_{4}\right)$ of Si-O-Si bending. In both cases extensive domains of absorption are observed rather than net bands and these are mainly characteristic of amorphous substances.

- The band existing at $790 \mathrm{~cm}^{-1}$ corresponds to vibrations of amorphous silica.

\subsection{Study of the puzzolana activity of the rice husk ash}

Assessing the possible puzzolana activity of a material has formed the main objective of a number of works, giving rise to different methods of assessment based on different aspects of the same fact.

For the present study an experiment has been conducted based on the experience of Dra. Luxán (19), to assess the material/slaked lime reaction, by means of the mechanical resistance test to bending and compression for mortars.

\subsubsection{Materials used}

- Rice husk ash. This ash was ground until a fineness of $4.500 \mathrm{~cm}^{3} / \mathrm{g}$ Blaine was attained, this being considered most appropriate for subsequent study.

- Slaked lime. The lime used was a calcium hydroxide, containing more than $90 \%$ $\mathrm{Ca}(\mathrm{OH})_{2}$ and with a $\mathrm{CO}_{2}$ content of less than $7 \%$.

- The sand used in the mortar is the standard one in RC-75 (10) for testing cements.

- Mixing water. The water/conglomerate ratio is 0,5 (although this value may be increased by certain materials until an adequate consistency is obtained so as to achieve good compacting).

\subsubsection{Procedure}

The samples are $4 \times 4 \times 16 \mathrm{~cm}$ prisms, made up according to specifications for cement mortar as described in RC-75. The mortar is 
mortero se realiza con $500 \mathrm{~g}$ de conglomerante material-cal, $1.500 \mathrm{~g}$ de arena normalizada y $250 \mathrm{~cm}^{3}$ de agua.

El conglomerante está constituido por tres partes de material objeto de estudio (RHA) y una parte de cal.

Las probetas se conservan en sus moldes durante $48 \pm 2$ horas, en una cámara a $21 \pm 2^{\circ} \mathrm{C}$ y a una humedad relativa superior al $90 \div 95 \%$. Una vez desmoldadas se introducen en un ambiente de vapor producido por agua a $50^{\circ} \pm 5^{\circ} \mathrm{C}$, durante $72 \pm 3$ horas. Una vez transcurrido este tiempo, se dejan enfriar las probetas en el interior del baño desconectado, hasta temperatura ambiente.

\subsubsection{Resultados}

En el caso de la ceniza de cáscara de arroz, el agua de amasado se aumentó hasta $330 \mathrm{cc}$, para conseguir una buena trabajabilidad. Este hecho debe tenerse en consideración a la hora de la utilización del material.

Las probetas se rompieron a flexión y compresión, dando como resultados medios los que figuran en la Tabla 3.

TABLA 3

\begin{tabular}{|c|c|c|}
\hline $\begin{array}{c}\text { RESISTENCIA } \\
\text { A FLEXO- } \\
\text { TRACCION } \\
\text { MPa }\end{array}$ & $\begin{array}{c}\text { RESISTENCIA } \\
\text { COMPRESION } \\
\text { MPa }\end{array}$ & $\begin{array}{c}\text { RELACION } \\
\text { a/c }\end{array}$ \\
\hline 0,68 & 6,96 & 0,66 \\
\hline
\end{tabular}

Si bien estos resultados son orientativos, permiten establecer si existe o no reacción con la cal y si el material objeto de estudio posee o no actividad puzolánica.

De los valores obtenidos se deduce que la ceniza de cáscara de arroz es un material de actividad media, de acuerdo con la clasificación establecida para estos materiales (19) en el ensayo anteriormente descrito.

\section{CONFORMACION DE CONGLOMERANTES. ENSAYOS DE MORTEROS}

En base al material residuo de la combustión de la cáscara (RHA) y mediante su mezcla con cal y cemento portland (ARI-450), se han made with $500 \mathrm{~g}$ of conglomerate material-lime, $1.500 \mathrm{~g}$ of standard sand and $250 \mathrm{~cm}^{3}$ of water.

The conglomerate consists of three parts of the material under study (RHA) and one part lime.

The samples are kept in their casts for $48 \pm 2$ hours, in a chamber at $21 \pm 2^{\circ} \mathrm{C}$ and a relative humidity of more than $90 \div 95 \%$. Once they have been decasted, they are placed in a steam environment produced by water at $50^{\circ} \pm 5^{\circ} \mathrm{C}$, for $72 \pm 3$ hours. Once this time has elapsed, the samples are left to cool inside the disconnected bath until they reach ambient temperature.

\subsubsection{Results}

In the case of rice husk ash, the mixing water was increased to $330 \mathrm{cc}$ so as to achieve good workability. This fact should be taken into account when the time comes to use the material.

The samples broke under bending and compression tests, giving the average results shown in Table 3.

TABLE 3

\begin{tabular}{|c|c|c|}
\hline $\begin{array}{c}\text { MPa } \\
\text { BENDING } \\
\text { STRENGTH }\end{array}$ & $\begin{array}{c}\text { MPa } \\
\text { COMPRESSIVE } \\
\text { STRENGTH }\end{array}$ & w/c RATIO \\
\hline 0,68 & 6,95 & 0,66 \\
\hline
\end{tabular}

Although these results are only meant for guidance, they enable us to ascertain whether or not there is any reaction with lime and whether or not the material under study has any puzzolana activity.

From the values obtained, it can be deduced that the rice husk ash is a material with average activity, in accordance with the classification established for these materials (19) in the test descried above.

\section{CONFIGURATION OF CONGLOMERATES. MORTAR TESTS}

Eight "conglomerates" were produced from the residue material from the combustion of the husk (RHA) by mixing this with lime and 
TABLA 4

Resultados de los análisis químicos de los siete conglomerantes a base de R.H.A.

\begin{tabular}{|c|r|r|r|r|r|r|r|r|}
\hline \multirow{2}{*}{$\begin{array}{c}\text { METER- } \\
\text { MINACIONES }\end{array}$} & \multicolumn{7}{|c|}{ M U E S TR A S } \\
\cline { 2 - 9 } & CLM-1 & CLM-2 & CLM-3 & \multicolumn{1}{c|}{ CLN } & P-ARI-450 & CAM-1 & CAM-2 & CAM-3 \\
\hline P.P.C. & 17,84 & 14,29 & 10,79 & 16,61 & 3,30 & 3,89 & 3,56 & 3,31 \\
R.I. & 17,11 & 20,96 & 29,16 & 17,35 & 1,79 & 10,16 & 25,11 & 36,85 \\
$\mathrm{SiO}_{2}$ & 13,25 & 23,83 & 30,02 & 16,99 & 17,90 & 30,86 & 32,31 & 34,51 \\
$\mathrm{Al}_{2} \mathrm{O}_{3}$ & 0,95 & 0,72 & 1,34 & 0,76 & 5,41 & 4,32 & 3,43 & 2,66 \\
$\mathrm{Fe}_{2} \mathrm{O}_{3}$ & 0,25 & 0,35 & 0,41 & 0,23 & 3,36 & 2,19 & 1,80 & 1,17 \\
$\mathrm{CaO}$ & 48,46 & 36,90 & 25,75 & 45,59 & 61,80 & 43,73 & 29,18 & 18,92 \\
$\mathrm{MgO}$ & 0,56 & 0,47 & 0,56 & 0,20 & 1,42 & 1,15 & 0,96 & 0,70 \\
$\mathrm{SO}_{3}$ & 0,72 & 0,60 & 0,49 & 0,66 & 3,35 & 2,45 & 1,90 & 1,12 \\
$\mathrm{Na}_{2} \mathrm{O}$ & 0,05 & 0,05 & 0,05 & 0,03 & - & 0,15 & 0,12 & 0,10 \\
$\mathrm{~K}_{2} \mathrm{O}$ & 0,76 & 0,78 & 0,92 & 0,67 & - & 1,28 & 1,34 & 1,14 \\
\hline TOTALES & 99,85 & 98,95 & 99,49 & 99,09 & 98,33 & 100,18 & 99,71 & 99,82 \\
\hline
\end{tabular}

TABLE 4

Results of chemical analyses of the seven conglomerates with an R.H.A. base

\begin{tabular}{|l|r|r|r|r|r|r|r|r|}
\hline \multirow{2}{*}{$\begin{array}{l}\text { DETERMI- } \\
\text { NATIONS }\end{array}$} & \multicolumn{7}{|c|}{ S A M P LE S } \\
\cline { 2 - 9 } & CLM-1 & CLM-2 & CLM-3 & CLN & P-ARI-450 & CAM-1 & CAM-2 & CAM-3 \\
\hline LOI & 17,84 & 14,29 & 10,79 & 16,61 & 3,30 & 3,89 & 3,56 & 3,31 \\
I.R. & 17,11 & 20,96 & 29,16 & 17,35 & 1,79 & 10,16 & 25,11 & 36,85 \\
$\mathrm{SiO}_{2}$ & 13,25 & 23,83 & 30,02 & 16,99 & 17,90 & 30,86 & 32,31 & 34,51 \\
$\mathrm{Al}_{2} \mathrm{O}_{3}$ & 0,95 & 0,72 & 1,34 & 0,76 & 5,41 & 4,32 & 3,43 & 2,66 \\
$\mathrm{Fe}_{2} \mathrm{O}_{3}$ & 0,25 & 0,35 & 0,41 & 0,23 & 3,36 & 2,19 & 1,80 & 1,17 \\
$\mathrm{CaO}$ & 48,46 & 36,90 & 25,75 & 45,59 & 61,80 & 43,73 & 29,18 & 18,92 \\
$\mathrm{MgO}$ & 0,56 & 0,47 & 0,56 & 0,20 & 1,42 & 1,15 & 0,96 & 0,70 \\
$\mathrm{SO}_{3}$ & 0,72 & 0,60 & 0,49 & 0,66 & 3,35 & 2,45 & 1,90 & 1,12 \\
$\mathrm{Na}_{2} \mathrm{O}$ & 0,05 & 0,05 & 0,05 & 0,03 & - & 0,15 & 0,12 & 0,10 \\
$\mathrm{~K}_{2} \mathrm{O}$ & 0,76 & 0,78 & 0,92 & 0,67 & - & 1,28 & 1,34 & 1,14 \\
\hline $\mathrm{TOTALS}^{*}$ & 99,85 & 98,95 & 99,49 & 99,09 & 98,33 & 100,18 & 99,71 & 99,82 \\
\hline
\end{tabular}

realizado ocho "conglomerantes", seis de ellos molidos en molino de bolas hasta conseguir $4.500 \mathrm{~cm}^{2} / \mathrm{g}$ Blaine y dos (CLN y CAN) mezclados manualmente. Las combinaciones estudiadas son las siguientes: portland cement (ARI-450). Six of these conglomerates were ground in ball mills until $4.500 \mathrm{~cm}^{3} / \mathrm{g}$ Blaine was obtained, and two (CLN and CAN) were mixed by hand. The combinations submitted to study are as follows: 


\begin{tabular}{|c|c|}
\hline CLAVE & COMPOSICION EN PESO \\
\hline CLN & $\begin{array}{l}\text { ( } 50 \% \text { cal }+50 \% \text { ceniza RHA mezcladas) sin } \\
\text { moler. }\end{array}$ \\
\hline CAN & $\begin{array}{l}\text { ( } 50 \% \text { de cemento P-ARI- } 450+\text { ceniza RHA) } \\
\text { sin moler. }\end{array}$ \\
\hline CLM 1 & $67 \%$ de cal $+33 \%$ ceniza (RHA) \\
\hline CLM 2 & $50 \%$ de cal $+50 \%$ ceniza $(\mathrm{RHA})$ \\
\hline CLM 3 & $33 \%$ de cal $+67 \%$ ceniza (RHA) \\
\hline CAM 1 & $67 \%$ P-ARI- $450+33 \%$ ceniza (RHA) \\
\hline CAM 2 & $50 \%$ P-ARI-450 + $50 \%$ ceniza (RHA) \\
\hline CAM 3 & $33 \%$ P-ARI-450 + $67 \%$ ceniza (RHA) \\
\hline
\end{tabular}

\begin{tabular}{|c|c|}
\hline KEY & COMPOSITION IN WEIGHT \\
\hline CLN & $\begin{array}{l}\text { (50\% Lime and } 50 \% \text { mixed RHA) without } \\
\text { grinding. }\end{array}$ \\
\hline CAN & $\begin{array}{l}\text { [50\% P-ARI-450 cement }+ \text { ash }(\mathrm{RHA})] \text { without } \\
\text { grinding. }\end{array}$ \\
\hline CLM 1 & $67 \%$ lime $+33 \%$ ash (RHA) \\
\hline CLM 2 & $50 \%$ lime $+50 \%$ ash $(\mathrm{RHA})$ \\
\hline CLM 3 & $33 \%$ lime $+67 \%$ ash $(\mathrm{RHA})$ \\
\hline CAM 1 & $67 \%$ P-ARI-450 + $33 \%$ ash (RHA) \\
\hline CAM 2 & $50 \%$ P-ARI-450 + $50 \%$ ash (RHA) \\
\hline CAM 3 & $33 \%$ P-ARI-450 + $67 \%$ ash (RHA) \\
\hline
\end{tabular}

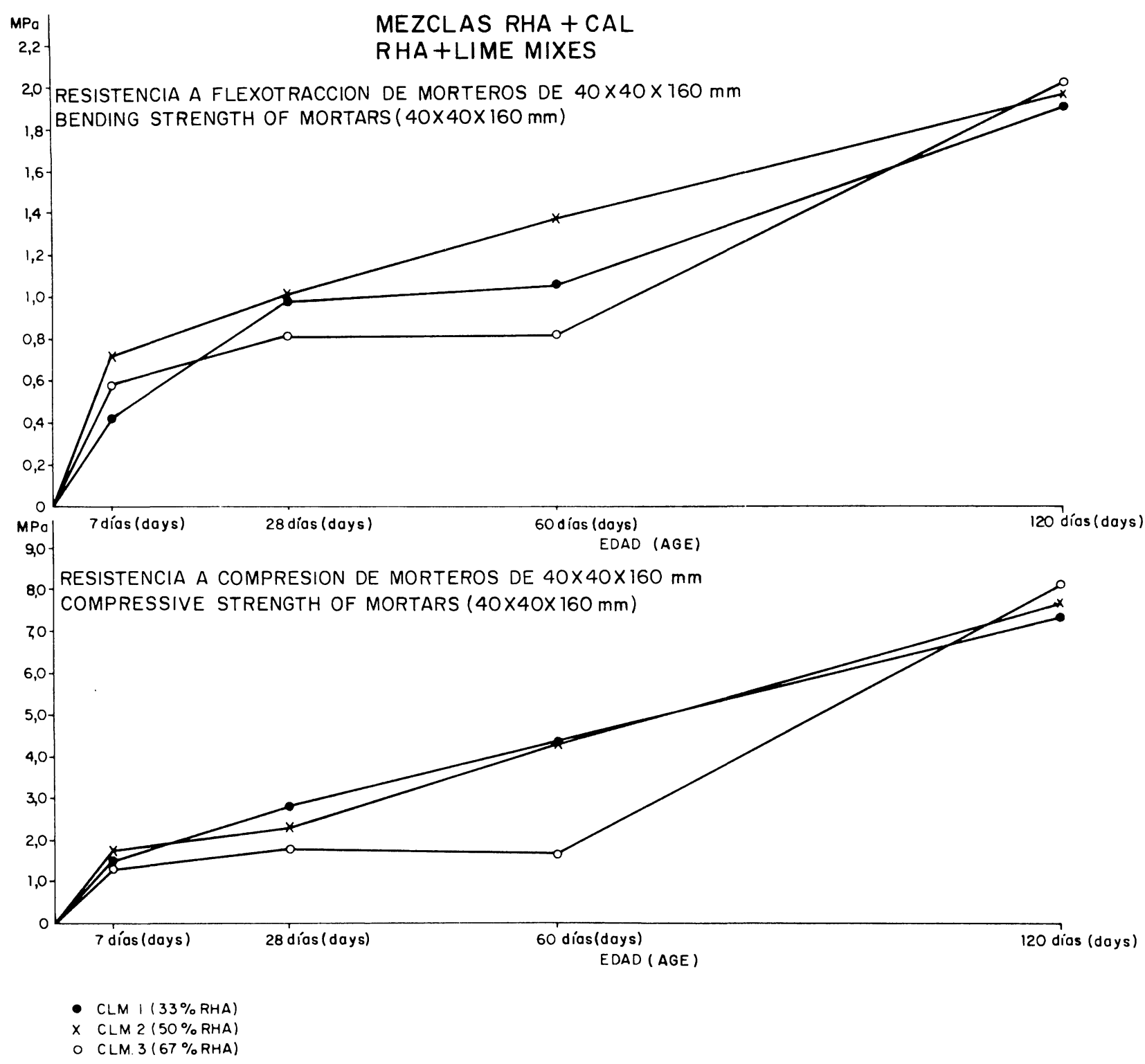

Fig. 6 
RESISTENCIA A FLEXOTRACCION DE MORTEROS DE $40 \times 40 \times 160 \mathrm{~mm}$ BENDING STRENGTH OF MORTARS $(40 \times 40 \times 160)$

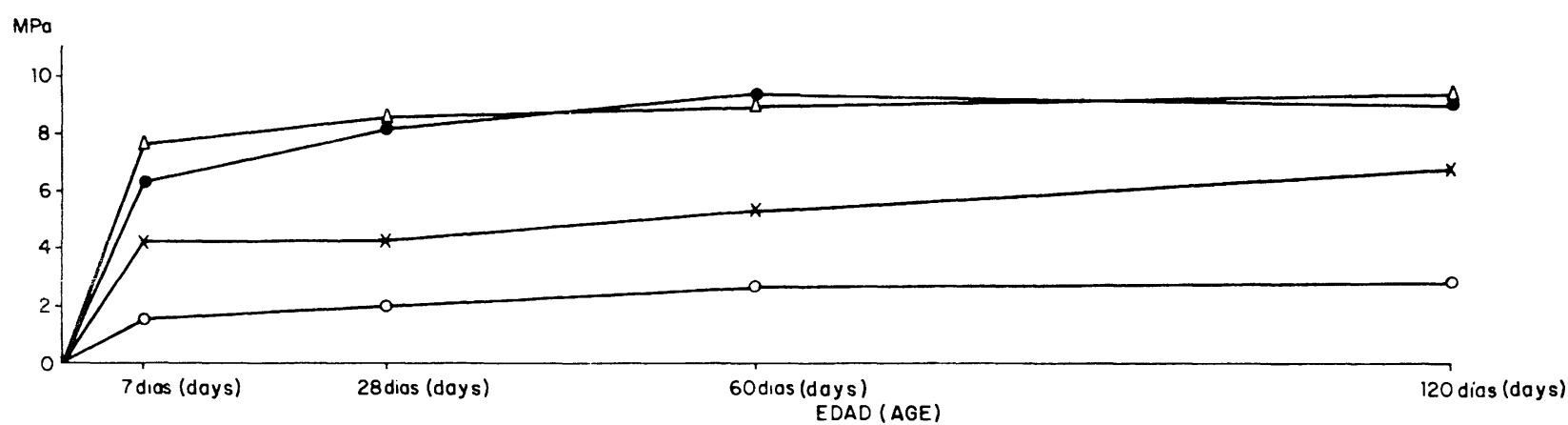

RESISTENCIA A COMPRESION DE MORTEROS DE $40 \times 40 \times 160 \mathrm{~mm}$ COMPRESSIVE STRENGTH OF MORTARS ( $40 \times 40 \times 160)$

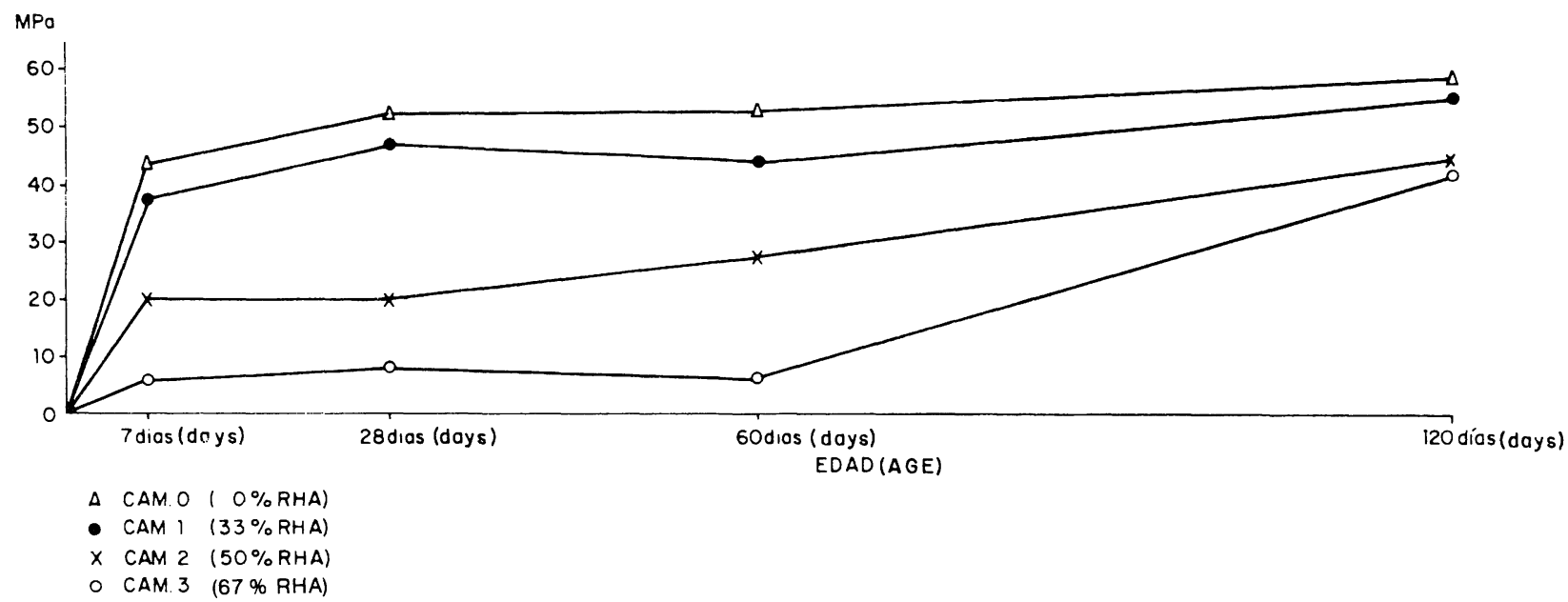

Fig. 7

De todos los "conglomerantes" se han realizado los correspondientes análisis químicos, resultando como composición de los mismos los que figuran en la Tabla 4. Igualmente se han realizado, de acuerdo con el pliego, los ensayos pertinentes a compresión y flexotracción. En las figuras 6 y 7 , se recogen los valores medios de tres resultados cada uno, así como en la Tabla 5 .

Para acortar la lenta reacción entre la ceniza (RHA) y la cal, Cook, Parma y Bishwendu (20) recomiendan añadir alúmina reactiva en forma de aluminato sódico, al objeto de disminuir el tiempo para la consecución de una resistencia a compresión determinada.

La conformación de silicato cálcico mediante la adición de cal hidráulica a la RHA se muestra satisfactoria; una proporción muy alta de cal puede retrasar en exceso la obtención de resistencias adecuadas a los fines que se
Chemical analyses have been conducted for all the "conglomerates", and the composition corresponding to each of these is shown in Table 4. Tests concerning compression and flexotraction have also been carried out, in accordance with specifications. The average values for three results in each case are given in Figs. 6 and 7, and also in Table 5.

In order to shorten the slow reaction between the ash (RHA) and the lime, Cook, Parma and Bishwendu (20) recommended adding reactive alumina in the form of sodium aluminate, so as to reduce the time needed to achieve a certain compressive strength.

The formation of calcium silicate by means of adding water lime to the RHA is seen to be satisfactory: a very high proportion of lime may excessively delay obtaining strengths which are adequate for the purposes of this work; 
TABLA 5

\begin{tabular}{|l|c|c|c|c|c|c|c|c|}
\hline \multirow{2}{*}{ MUESTRA } & \multicolumn{4}{|c|}{$\begin{array}{c}\text { RESISTENCIA A } \\
\text { FLEOTRACCION (MPa) }\end{array}$} & \multicolumn{4}{c|}{$\begin{array}{c}\text { RESISTENCIA A } \\
\text { COMPRESION (MPa) }\end{array}$} \\
\cline { 2 - 9 } & $\mathbf{7}$ dias & $\mathbf{2 8}$ dias & $\mathbf{6 0}$ días & $\mathbf{1 2 0}$ días & $\mathbf{7}$ días & $\mathbf{2 8}$ días & $\mathbf{6 0}$ días & $\mathbf{1 2 0}$ días \\
\hline CLM-1 & 0,42 & 0,98 & 1,07 & 1,92 & 1,48 & 2,80 & 4,42 & 7,23 \\
CLM-2 & 0,72 & 1,02 & 1,39 & 1,98 & 1,69 & 2,30 & 4,37 & 7,64 \\
CLM-3 & 0,58 & 0,82 & 0,82 & 2,02 & 1,46 & 1,80 & 1,63 & 8,08 \\
\hline P-ARI-450 & 7,60 & 8,70 & 9,10 & 9,07 & 44,00 & 53,10 & 54,00 & 59,00 \\
CAM-1 & 6,30 & 8,10 & 9,25 & 8,97 & 37,85 & 47,00 & 44,15 & 55,98 \\
CAM-2 & 4,18 & 4,10 & 5,27 & 6,72 & 20,52 & 20,50 & 27,83 & 43,11 \\
CAM-3 & 1,53 & 2,00 & 2,77 & 2,67 & 5,90 & 7,50 & 6,44 & 11,58 \\
\hline
\end{tabular}

TABLE 5

\begin{tabular}{|c|c|c|c|c|c|c|c|c|}
\hline \multirow{2}{*}{ SAMPLE } & \multicolumn{4}{|c|}{$\begin{array}{c}\text { BENDING } \\
\text { STRENGTH (MPa) }\end{array}$} & \multicolumn{4}{|c|}{$\begin{array}{l}\text { COMPRESSIVE } \\
\text { STRENGTH (MPa) }\end{array}$} \\
\hline & 7 days & 28 days & 60 days & 120 days & 7 days & 28 days & 60 days & 120 days \\
\hline CLM-1 & 0,42 & 0,98 & 1,07 & 1,92 & 1,48 & 2,80 & 4,42 & 7,23 \\
\hline CLM-2 & 0,72 & 1,02 & 1,39 & 1,98 & 1,69 & 2,30 & 4,37 & 7,64 \\
\hline CLM-3 & 0,58 & 0,82 & 0,82 & 2,02 & 1,46 & 1,80 & 1,63 & 8,08 \\
\hline P-ARI-450 & 7,60 & 8,70 & 9,10 & 9,07 & 44,00 & 53,10 & 54,00 & 59,00 \\
\hline CAM-1 & 6,30 & 8,10 & 9,25 & 8,97 & 37,85 & 47,00 & 44,15 & 55,98 \\
\hline CAM-2 & 4,18 & 4,10 & 5,27 & 6,72 & 20,52 & 20,50 & 27,83 & 43,11 \\
\hline CAM-3 & 1,53 & 2,00 & 2,77 & 2,67 & 5,90 & 7,50 & 6,44 & 11,58 \\
\hline
\end{tabular}

propone este trabajo; relaciones cal/ceniza $1 / 2$ parecen las más adecuadas, en el contexto del trabajo, en el que ni las altas resistencias, ni el rápido fraguado son propiedades fundamentales.

\subsection{Conclusiones}

A la vista de los resultados de los ensayos mecánicos sobre morteros hasta 120 dias se deducen provisionalmente algunos resultados de carácter inmediato:

- Las resistencias obtenidas para los tres "conglomerantes" a base de RHA y cemento son marcadamente superiores a las conseguidas mediante RHA y cal.

- La necesidad de moler la RHA hasta conseguir una finura adecuada es absolutamente imprescindible, ya que lime/ash ratios $\simeq 1 / 2$ appear to be the most suitable, within the context of this work, in which neither high levels of resistance nor quick setting are fundamental properties.

\subsection{Conclusions}

In light of the results obtained for mechanical tests on mortars of up to 120 days certain results of an immediate nature may be deduced provisionally:

- The levels of resistance obtained for the three "conglomerates" based on RHA and cement are noticeably higher than those achieved with RHA and lime.

- The need to grind RHA until an adequate degree of fineness has been obtained is absolutely essential, since mixing by hand 
mediante la mezcla manual (conglomerantes CLN y CAN) resultan morteros prácticamente inviables desde la ejecución de las probetas.

- A efecto de necesidades resistentes típicas en las realizaciones de viviendas de bajo coste, y a reserva de otras características que han de estudiarse en profundidad, los conglomerantes CAM 1 y CAM 2 presentan valores a compresión y flexotracción suficientes para ser utilizables en este tipo de usos.

- A la vista de la experiencia adquirida se iniciará un trabajo sobre hormigones a base de RHA-cemento, en la que se buscará la aplicabilidad práctica de éstos conglomerantes, así como el profundizar en algunas de sus peculiaridades: relación a/c; trabajabilidad; durabilidad; influencia de la superficie específica; tipos de curados; etc.

- Parece oportuno estudiar el comportamiento de distintas combinaciones porcentuales a base de RHA, cemento y cal.
(CLN and CAN conglomerates) results in mortars that are virtually impracticable from the moment the samples are made up.

- For the purposes of typical resistance needs in the construction of low-cost housing, with the exception of other characteristics that have yet to be studied in depth, the CAM-1 and CAM-2 conglomerates present values for compression and flexotraction that are sufficient for them to be put to this type of use.

- In light of the experience acquired, a projet will be started on concretes with a RHA-cement base, in which the practical applicability of these conglomerates will be investigated, as well as delving deeply into some of its peculiarities: $w / c$ ratio; workability; influence of the specific surface; types of curing process, etc.

- It would seem to be in order to study the behaviour of combinations with different percentages or RHA, cement and lime.

\section{B I B L IOGRAFIA}

(1) J. SALAS, J. VERAS: "Insulating panels with rice husk", House and Sciene and its Aplications, Vol. 10, n.o 1. Miami (USA).

(2) J. SALAS, M. ALVAREZ, J. VERAS: "Lights/insulating concrete with rice-husk". Cement and Composites. Sheffield, U.K. 1986.

(3) P. K. MENTHA and N. PITT: "A new process of rice husk utilization". Proceedings of the "Rice By-products utilization", págs. 45 a 58 . Valencia IATA, Sept., 1974.

(4) DAVID F. HOUSTON: "Rice Hulls", cp. 12 del libro "Rice, chemistry and Technology". Am: Ass. Cereal Chem. Inc., Minnesota (USA), 512 p. 1972.

(5) RAY SMITH: "Rice husk Ash Cement, Progress in development and application". Intermediate Tecnology Development Group Limited, 45 pgs. Londres, 1984.

(6) Moayad N. AL-KHALAF and Hana A. YOUSIF: "Use of Rice husk and concrete". Cement and Composittes, Volumen 6, Numbeer 4, November, 1984. Págs. 241-248.

(7) R. C. MAHESWARI and T. P. OJHA: "Fuel characteristics of rice husk". Proceeding of the "Rice by-products utilization", págs. 67-76. Valencia IATA, Sept., 1974.

(8) P. BARTHA and E. A. HUPPERTZ: "Structure and crystallization of silice and the rice husk". Proceeding of the "Rice by products utilization", págs. 89-98. Valencia, IATA, Sept., 1974.

(9) E. C. FIEGER: "Basic and applied research needs for optimizin utilization of rice husk". Proceeding of the "Rice by-products utilization". Valencia, IATA, Sept., 1974.

(10) Pliego de Prescripciones Técnicas Generales para la Recepción de Cementos (RC-75). B.O.E. 28-29, Agosto, 1974.

(11) G. HARSCH: "Analysis of rice hulls and ash". Private communication to D. F. Houston (4). Año 1970.

(12) R. HAWKEY: "Rice husk utilization". International Conference. Volume I, pág. 59. Valencia, IATA, 1974.

(13) Norma UNE 80302: "Cementos. Especificaciones químicas para sus contribuyentes" (Octubre 1985).

(14) A. M. NEVILLE: "Properties of concrete". Editor Pitman, London, 1981.

(15) Proyecto de norma UNE 7144: "Determinación de la finura de los elementos con el Permeabilimetro Blaine".

(16) A. ANGLADETTE: "Le riz". Edit. Maisonneuve et Larose. París, 1966. 
(17) M. P. LUXAN: "Estudio de las puzolanas de origen volcánico, mediante espectroscopía de absorción de infrarrojo". Cuadernos de Investigación, n.॰ 32. I. E. Torroja. Marzo 1976.

(18) M. P. DE LUXAN; T. VAZQUEZ: "Il gelo di silice come pozzolana di riferimento: sua notevole attivitá e suoi limiti". II Cemento, Vol. 71, Sept., 1974.

(19) M. P. LUXAN; M. I. SANCHEZ ROJAS: "Estudio de la aptitud de un material como adición activa al cemento". Materiales de construcción, n. 199. I. E. Torroja. 1985.

(20) D. COOK, R. PARMA y P. BISHWENDU: "Rice husk ash-limecement mixes for use in masonry units". Build Environ, Vol. 12, n. 2, págs. 281-287, 1977.

\section{publicaciones del i.e.t.c.c.}

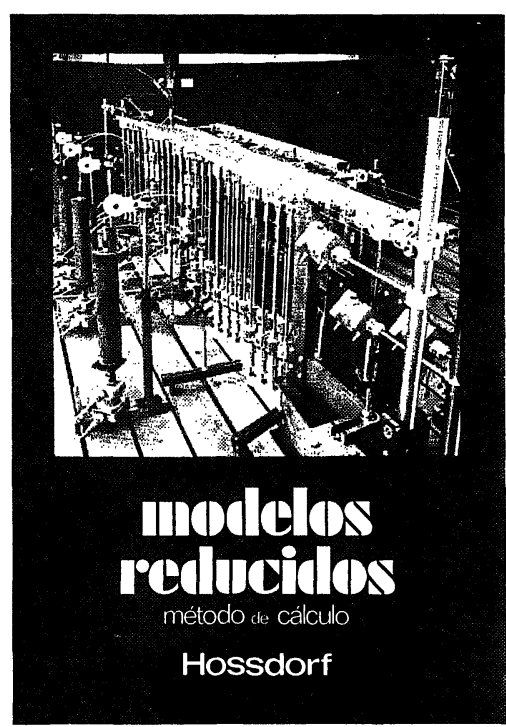

Modelos reducidos. Método de cálculo

H. Hossdorf, Ingeniero Civil

La técnica de los ensayos en modelos reducidos de estructuras sufre hoy dia una decisiva metamorfosis. Hasta hace poco era un medio más bien de artesania, que no sienpre acanto que se acudió las más de las veces, como a un que se acudio las mas de las veces, como a un cias. Sin embargo, en poco tiempo $y$ gracias a su cias. Sin embargo, en poco tiempo y gracias a su formado en un instrumento cientificamente valioso que no puede quedar a un lado en la práctica diaria del Ingeniero Proyectista.

Un volumen encuadernado en cartoné plastificado 250 páginas, 158 figuras y fotografias.

Precios: 1.800 ptas.; \$ USA 26.00

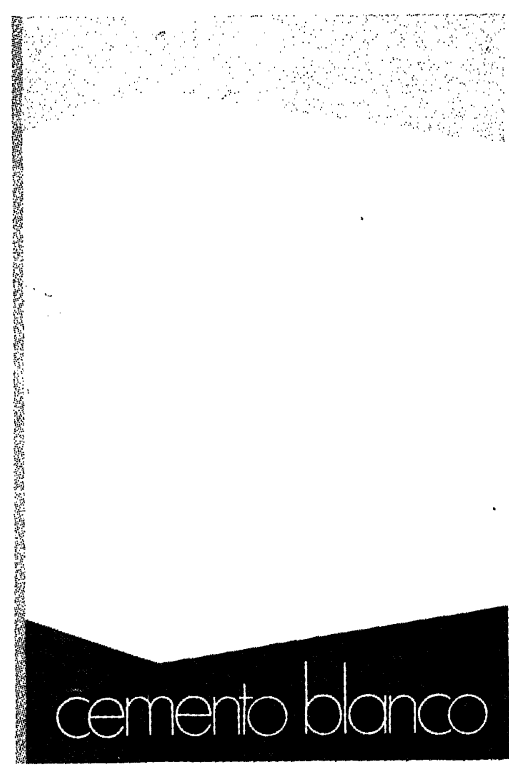

Cemento blanco

Julián Rezola

Ingeniero Quimico Dipl. I. Q. S

Sabido es que existe una extensa y documentada bibliografia sobre el cemento gris: en cambio, no puede decirse lo mismo acerca del cemento portland blanco, ya que los escritos existentes se refieren tan sólo a algunas peculiaridades que le distinguen de aquél.

El autor nos ofrece sus profundos conocimientos y su larga experiencia tanto en laboratorio como en fabricación.

La parte descriptiva del libro se complementa con gráficos, diagramas y fotografias de gran utilidad destinados a conseguir la aplicación apropiada de este aglomerante.

Un volumen encuadernado en cartoné policerado, de vesto de 395 páginas,

Precios: España, 1.700 ptas.; extranjero, $\$ 24.00$

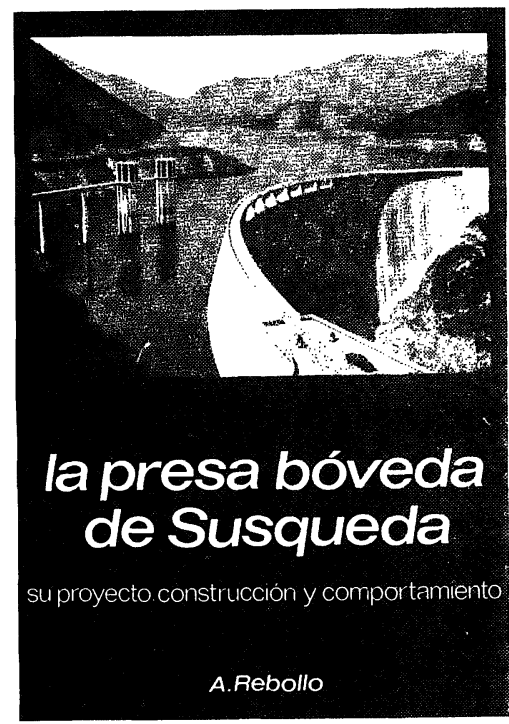

La presa bóveda de Susqueda

A. Rebollo,

Dr. Ingeniero de Caminos

El esfuerzo del constructor de presas se sitúa. por su pretensión de perennidad, a contracorriente de las tendencias de la civilización actual, caracte rizada por lo fungible. Pueden evocarse las 10.000 grandes. presas en funcionamiento o en construcción que están envejeciendo y reclaman los cuidados gerontológicos para mantener y perfeccionar su servicio y garantizar su inalienable pretensión de perennidad. En la medida en que todas nuevas obras, grandes o pequeñas, son portadoras de riesgos ecologicos $y$, a veces, catastróficos, que aumentan con el envejecimiento, la gerontologia de las presas es todo un emplazo. La acciòn adelantada de Anturo Rebollo un este terreno marca un camino a seguir para todos los que aman su propia obra con

Un volumen encuadernado en cartoné plastificado Un volumen encuadernado en cartone plastificado 408 páginas, 330 figuras y fotografias y 39 tablas. Precios: 1.700 ptas.; extranjero, \$ USA 24.00. 